\title{
O JULGAMENTO DA ADI N 3510 SOB A PERSPECTIVA ARGUMENTATIVA ${ }^{1}$
}

The judgment of case ADI 3510 of the Brazilian Supreme Court from an argumentative perspective El juicio de la adi $n^{\circ} 3510$ desde un punto de vista argumentativo Claudia Rosane Roesler ${ }^{2}$

Gabriel Rübinger-Betti ${ }^{3}$

1 Artigo elaborado como Relatório Final do Programa de Iniciação Científica da Universidade de Brasília (ProIC), Edital 2013/2014, sob orientação e coautoria da Profa. Dra. Claudia Rosane Roesler, dentro do projeto de pesquisa "Argumentação Judicial e Controle Racional: o 'Estado da Arte' da Justificação das Decisões Judiciais nos Tribunais Superiores Brasileiros".

2 Professora da Faculdade de Direito da Universidade de Brasília, Doutora em Filosofia e Teoria Geral do Direito pela Universidade de São Paulo - USP, Bolsista de Produtividade em Pesquisa do CNPq.

3 Graduando em Direito, Universidade de Brasília. E-mail: rubinger.g@gmail.com 
Resumo: O presente trabalho tem como objetivo avaliar a argumentação desenvolvida pelo Supremo Tribunal Federal no julgamento da ADI (Ação Direta de Inconstitucionalidade) $n^{\circ}$ 3510. O ponto central da discussão do caso é a interpretação do artigo $5^{\circ}$ da Lei $n^{\circ}$ 11.105/05 (Lei de Biossegurança), que autoriza a pesquisa com células-tronco embrionárias. Após o exame dos votos segundo o esquema de Stephen Toulmin e a análise à luz da teoria de Neil MacCormick, pode-se dizer que os votos são apropriadamente fundamentados do ponto de vista individual. Porém, o julgamento apresenta inconsistências internas, demonstrando certa discordância quanto aos fundamentos jurídicos, mesmo entre Ministros e Ministras que votaram em sentido igual. Portanto, considera-se que tal decisão não foi a mais adequada diante dos ideais de um Estado Democrático de Direito e da exigência de fundamentação das decisões judiciais a eles inerente.

Palavras-chave: ADI n 3510. Lei de Biossegurança. Argumentação Jurídica. Estado Democrático de Direito.

Abstract: This study analyzes the argumentation developed by the Brazilian Supreme court in the judgment of the case entitled "Ação Direta de Inconstitucionalidade 3510" (ADI 3510). The central point in the discussion of this case is the interpretation of Article 5 of the Brazilian Biosafety Law (Law no. 11,105 of March 24, 2005), which authorized research with embryonic stem cells. After examining the votes using Stephen Toulmin's layout, and analyzing in light of the theory of Neil McCormick, it can be said that the votes are correctly grounded from the individual point of view. Nevertheless, the judgment as a whole presents internal inconsistencies, demonstrating a certain disagreement as to the legal grounds, even among the Ministers who voted the same way. We conclude that this decision was not the most appropriate, in view of the ideals of a Democratic Sate of Law, and the requirement to state the grounds inherent to it. 
Keywords: ADI n 3510. Brazilian Biosafety Law. Legal Argumentation. Rule of Law.

Resumen: El presente trabajo tiene como objetivo evaluar la argumentación desarrollada por el Supremo Tribunal Federal en el juicio de la ADI (Acción Directa de Inconstitucionalidad) $n^{\circ} 3510$. El punto central de la discusión del caso es la interpretación del artículo $5^{\circ}$ de la Ley $n^{\circ}$ 11.105/05 (Ley de Bioseguridad), que autoriza la investigación con células tronco embrionarias. Tras el examen de los votos según el esquema de Stephen Toulmin y el análisis a la luz de la teoría de Neil MacCormick, se puede decir que los votos están apropiadamente fundamentados desde el punto de vista individual. Sin embargo, el juicio presenta inconsistencias internas, demostrando cierta discordancia en relación a los fundamentos jurídicos, incluso entre Ministros y Ministras que votaron en el mismo sentido. Por lo tanto, se considera que tal decisión no fue la más adecuada frente a los ideales de un Estado Democrático de Derecho y a la exigencia de fundamentación de las decisiones judiciales inherente a ellos.

Palabras clave: ADI n 3510. Ley de Bioseguridad. Argumentación Jurídica. Estado Democrático de Derecho.

INTRODUÇÃO

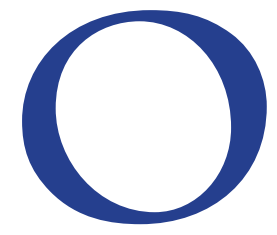

Estado de Direito pode ser entendido como um ideal político essencialmente procedimental, que se concretiza de forma mais ou menos intensa a depender do funcionamento das instituições desse sistema. ${ }^{4}$ Os tribunais e as leis se aproximam desse ideal no desenrolar da prática jurídica, de modo que a argumentação desempenha um papel central nesse processo.

Ao expor as razões que motivaram a decisão, o juiz consagra a própria ordem democrática, pois sua posição no caso concreto se torna passível de crítica. 4 WALDRON, Jeremy. The concept and the Rule of Law. In: HeinOnline $\mathbf{4 3}$ Ga. L. Rev. 1 (2008-2009), p. 56-61. 
Isso garante aos cidadãos um mínimo de igualdade diante da lei e da limitação do poder jurisdicional, pois se as leis e as decisões possuíssem apenas um "simulacro de inteligibilidade", qualquer coisa poderia acontecer, dada a natural indeterminação dos textos legais. ${ }^{5}$

A exigência da fundamentação das decisões judiciais é direito assegurado pela Constituição Federal (art. 93, IX), sob pena de nulidade, de forma que a própria legitimidade da decisão judicial depende da justificação da racionalidade da decisão. ${ }^{6}$ Dessa forma, a atividade argumentativa desempenha um papel central em um estado democrático. Na medida em que os juízes fundamentam suas decisões expondo seus argumentos, estas se tornam passíveis de crítica. Mesmo a decisão que aparente ser parcial deve se fundamentar segundo regras e princípios de um sistema jurídico, cuja aplicação pode ser questionada.

O presente trabalho tem como objetivo avaliar a argumentação desenvolvida pelos ministros no julgamento da ADI (Ação Direta de Inconstitucionalidade) $n^{\circ}$ 3510, que tratava da pesquisa com células-tronco embrionárias. Nosso objetivo é discutir, à luz das teorias argumentativas, se os argumentos levantados no caso podem ser considerados racionalmente persuasivos - ou seja, se poderiam convencer um hipotético espectador imparcial a tomar as mesmas decisões, sobre as mesmas circunstâncias.

\section{O CONTEXTO DA LEI N 3510/05 E A ADI N 3510}

As células-tronco embrionárias são células retiradas do blastocisto (embrião em estado de pré-implantação) e que são capazes de se diferenciar em outras células do organismo, como células musculares ou ósseas. Ao contrário das células-tronco adultas, as células-tronco embrionárias são totipotentes - podem se transformar em células de qualquer tecido presente no organismo adulto. Por possuírem essa capacidade extraordinária de diferenciação, as pesquisas com células-tronco são promissoras.

5 MACCORMICK, Neil. Retórica e Estado de Direito. Tradução de Conrado Hubner Mendes. Rio de Janeiro: Elsevier, 2008, p. 2.

6 MARINONI, Luiz Guilherme. Teoria Geral do Processo. 3. ed. São Paulo: Editora Revista dos Tribunais, 2008, p. 108. 
Quando se extrai a célula-tronco embrionária, no entanto, ocorre a destruição do embrião, o que levanta diversas questões polêmicas do ponto de vista ético, já que o embrião é considerado por muitos o início da vida humana. Justamente por envolver tantos aspectos - jurídicos, morais, religiosos -, o problema é de grande complexidade.

A autorização das pesquisas com células-tronco embrionárias tem início com a Lei $n^{\circ} 11.105 / 05$, que no ordenamento jurídico brasileiro surge como uma tentativa de reordenar as várias normas em vigor que tratavam da biossegurança, como a Lei $n^{\circ}$ 8.974/95 e a Medida Provisória $n^{\circ}$ 2.191-9/01, delimitando as normas de segurança e os mecanismos de fiscalização envolvendo organismos geneticamente modificados (OGMs). A Lei remonta ao PL 2401/2003, em cuja justificação se buscava, além do já citado, "atender, em sua plenitude, o Princípio da Precaução, definido em vários instrumentos internacionais dos quais o Brasil é signatário e presente no art. 225 da Constituição Federal, tornando efetiva a ação do Estado na proteção da saúde humana e do meio ambiente no trato dessa matéria polêmica internacionalmente". ${ }^{7}$

O substitutivo aprovado pela Câmara dos Deputados vedava qualquer manipulação genética ou manejo de organismos in vitro, inclusive a manipulação genética de células germinais humanas. A autorização das pesquisas com célulastronco embrionárias surgiu apenas quando a proposta passou pela Comissão de Educação no Senado Federal, que acrescentou o dispositivo e tomou a redação final no tocante ao assunto quando tramitou na Comissão de Constituição, Justiça e Cidadania, de Assuntos Econômicos e Assuntos Sociais. Portanto, é interessante notar que ainda no Congresso Federal o tema despertou várias divergências.

Essa controvérsia norteou boa parte dos debates legislativos e se intensificou na sociedade após a sanção da Lei, em 25 de março de 2005. Pouco mais de dois meses após a sanção presidencial, o Procurador Geral da República ingressou com uma Ação Direita de Inconstitucionalidade, visando impugnar o art. $5^{\circ}$ da Lei, que versava sobre a pesquisa com células-tronco embrionárias:

7 BRASIL. Congresso Nacional. PL 2401/2003. Inteiro Teor da Apresentação do Projeto de Lei pelo Poder Executivo, outubro de 2003, p. 15. 
Art. 5o É permitida, para fins de pesquisa e terapia, a utilização de células-tronco embrionárias obtidas de embriões humanos produzidos por fertilização in vitro e não utilizados no respectivo procedimento, atendidas as seguintes condições:

I - sejam embriões inviáveis; ou

II - sejam embriões congelados há 3 (três) anos ou mais, na data da publicação desta Lei, ou que, já congelados na data da publicação desta Lei, depois de completarem 3 (três) anos, contados a partir da data de congelamento.

$\S 1$ o Em qualquer caso, é necessário o consentimento dos genitores.

§ 20 Instituições de pesquisa e serviços de saúde que realizem pesquisa ou terapia com células-tronco embrionárias humanas deverão submeter seus projetos à apreciação e aprovação dos respectivos comitês de ética em pesquisa.

§ 3o É vedada a comercialização do material biológico a que se refere este artigo e sua prática implica o crime tipificado no art. 15 da Lei ${ }^{\circ}$ 9.434, de 4 de fevereiro de $1997 .{ }^{8}$

$\mathrm{Na}$ petição inicial foi acentuada a inviolabilidade do direito à vida e à dignidade da pessoa humana como fundamento do Estado Democrático de Direito, e que a vida humana ocorre a partir da fecundação. Nesse entendimento, as células-tronco embrionárias seriam vida humana inviolável, protegidas pela Constituição, devendo a lei ser considerada inconstitucional. Ao ser recebida pelo STF, percebeu-se a complexidade da matéria, e foi convocada uma audiência pública para debater o tema (a primeira a ser convocada pelo tribunal) em que se confrontaram diversos especialistas e representantes sobre o assunto, tanto do campo científico quanto da sociedade civil.

O STF decidiu pela improcedência da ação, permitindo as pesquisas com células-tronco embrionárias, em um julgamento de grande repercussão na sociedade. O ministro relator da ação, Ayres Britto, votou pela improcedência (e 
consequente constitucionalidade da Lei) e outros cinco ministros seguiram seu entendimento. Cinco ministros votaram em sentido contrário, divergentes em graus diversos, mas nenhum pela procedência total da ação.

Dessa forma, percebe-se a relevância do caso em questão, que trata de matéria controversa e que exige uma solução consciente dessa complexidade. Antes, porém, de se debruçar sobre a análise da argumentação e da correção do caso, esclarecer-se-á a metodologia empregada neste trabalho.

\section{A ARGUMENTAÇÃO JURÍDICA NA ADI N 3510: DOS VOTOS AO LAYOUT DE TOULMIN}

Nesse primeiro momento, buscou-se traduzir os votos do julgamento em questão para um esquema racional de análise, que permita observar os argumentos centrais de cada voto. Para tanto, utilizar-se-á o layout de argumentos proposto por Stephen Toulmin na sua obra Os usos do argumento.

Buscando ir além da lógica formal, Toulmin propôs um esquema para análise da argumentação baseado nos seguintes elementos:

a. Alegação ou conclusão (claim): é ao mesmo tempo o ponto de partida e de chegada da argumentação. ${ }^{9}$ É aquilo que pretendemos afirmar, cujo mérito buscamos estabelecer no decurso da argumentação. ${ }^{10}$

b. Dados (data): são os fatos ou informações aos quais recorremos como fundamento para alegação que estamos defendendo. ${ }^{11}$

c. Garantia (warrant): são proposições gerais que servem como ponte entre os dados e a conclusão, de forma incidental e explanatória, para mostrar a pertinência e legitimidade em se passar dos dados à conclusão apresentada. ${ }^{12}$

9 ATIENZA, Manuel. Las razones del derecho: teorías de la argumentación jurídica. 2. ed. México: Universidad Nacional Autónoma de México, 2005, p. 84.

10 TOULMIN, Stephen E. Os usos do argumento. Trad. Reinaldo Guarany. 2. ed. São Paulo: Martins Fontes, 2006, p. 140.

11 TOULMIN, Stephen E. Os usos do argumento, p. 140.

12 TOULMIN, Stephen E. Os usos do argumento, p. 141-143. 
d. Apoio (backing): são "avais" das garantias, que garantem a validade, relevância e vigência destas. Podem variar consideravelmente de acordo com o campo da argumentação. ${ }^{13}$

e. Qualificadores modais (qualifiers): são referências ao grau de força que os dados conferem à alegação, tendo em conta a garantia. São exemplos: necessariamente, provavelmente, presumivelmente. ${ }^{14}$

f. Condições de refutação (conditions of rebuttal): são circunstâncias nas quais se afasta a autoridade geral da garantia. Afastam a aplicabilidade da garantia no caso, refutando a conclusão garantida. ${ }^{15}$

Nos julgamentos de cortes superiores, como no caso do STF, geralmente não se apreciam questões de fato, mas somente questões de direito, o que imprime um caráter distinto aos elementos do argumento. Nas questões de direito, os dados "não serão apenas os fatos declarados provados pelo tribunal de instância, mas também as decisões de outros tribunais de apelação, normas, declarações de autoridades, etc." ${ }^{16}$ A garantia será uma norma jurídica geral ou um princípio jurídico; e o apoio consistirá na indicação de que a garantia enuncia uma norma ou princípio vigente. ${ }^{17}$ É preciso ressaltar que a apresentação dos argumentos aqui, segundo o layout de Stephen Toulmin, é um recorte daquilo que se considera a parte mais relevante da decisão, para efeitos de ilustração. Outros aspectos e argumentos igualmente relevantes, mas aqui omitidos, serão discutidos em seguida, quando se realizará a análise à luz da teoria de Neil MacCormick.

MINISTRO AYRES BRITTO

O Ministro Carlos Ayres Britto, relator da ADI n 3510, votou no sentido da improcedência da ação. Cinco ministros seguiram seu entendimento: Ellen Gracie, Carmen Lúcia, Joaquim Barbosa, Marco Aurélio e Celso de Mello, sendo os votos vencedores do julgamento. Em linhas gerais, seu voto gira em torno da 13 TOULMIN, Stephen E. Os usos do argumento, p. 148-149.

14 TOULMIN, Stephen E. Os usos do argumento, p. 144-145.

15 TOULMIN, Stephen E. Os usos do argumento, p. 145.

16 ATIENZA, Manuel. Las razones del derecho: teorías de la argumentación jurídica, p. 97. Tradução livre.

17 ATIENZA, Manuel. Las razones del derecho: teorías de la argumentación jurídica, p. 97. 
ideia de que a proteção da vida e da dignidade da pessoa humana são princípios essencialmente distintos: enquanto o primeiro só é aplicável aos nascidos com vida, o segundo admite transbordamento, protegendo a vida antes do nascimento. Essa proteção, no entanto, é gradativa, e aumenta de acordo com o desenvolvimento do organismo.

\section{O alcance do direito à vida}

\begin{tabular}{|c|c|}
\hline Dados & $\begin{array}{l}\text { "[...] a nossa Magna Carta não diz quando começa a vida humana. Não } \\
\text { dispõe sobre nenhuma das formas de vida humana pré-natal. Quando fala } \\
\text { da 'dignidade da pessoa humana' (inciso III do art. } 1^{\circ} \text { ), é da pessoa humana } \\
\text { naquele sentido ao mesmo tempo notarial, biográfico, moral e espiritual. [...] E } \\
\text { quando se reporta a "direitos da pessoa humana" [...] está falando de direitos e } \\
\text { garantias do indivíduo-pessoa. Gente. Alguém". }\end{array}$ \\
\hline Garantia & $\begin{array}{l}\text { "Donde a interpretação de que é preciso vida pós-parto para o ganho de uma } \\
\text { personalidade perante o Direito [...]. Mas personalidade como predicado ou } \\
\text { apanágio de quem é pessoa numa dimensão biográfica, mais que simplesmente } \\
\text { biológica". }\end{array}$ \\
\hline Apoio & Código Civil, art. $2^{\circ}$ e lição de José Afonso da Silva. \\
\hline Conclusão & $\begin{array}{l}\text { "[...] a Constituição Federal não faz de todo e qualquer estádio da vida humana } \\
\text { um autonomizado bem jurídico, mas da vida que já é própria de uma concreta } \\
\text { pessoa, porque nativiva, e nessa condição, dotada de compostura física ou } \\
\text { natural. [...] E como se trata de uma Constituição que sobre o início da vida } \\
\text { humana é de um silêncio de morte (permito-me o trocadilho), a questão não } \\
\text { reside exatamente em se determinar o início da vida do homo sapiens, mas em } \\
\text { saber que aspectos ou momentos dessa vida estão validamente protegidos } \\
\text { pelo Direito infraconstitucional e em que medida". }{ }^{3}\end{array}$ \\
\hline
\end{tabular}


A necessidade de atividade encefálica para configurar vida humana

\begin{tabular}{|l|l|}
\hline Dado & $\begin{array}{l}\text { "[...] vida humana já rematadamente adornada com o atributo da personalidade } \\
\text { civil é o fenômeno que transcorre entre o nascimento com vida e a morte } \\
\text { cerebral". }\end{array}$ \\
\hline Garantia & $\begin{array}{l}\text { Os "pressupostos de aplicabilidade" da seguinte lei: "a retirada post mortem } \\
\text { de tecidos, órgãos ou partes do corpo humano destinados a transplante ou } \\
\text { tratamento deverá ser precedida de diagnóstico de morte encefálica [...] (Lei } \\
n^{\circ} 9434, \text { art. } 3^{\circ}, \text { caput)".5 }\end{array}$ \\
\hline Apoio & $\begin{array}{l}\text { A Lei no } 9434 / 97, \text { art. } 3^{\circ},{ }^{\circ} \text { caput. } \\
\text { "[É] permitido fazer coincidir a morte encefálica com a cessação da vida de uma } \\
\text { dada pessoa humana; }[. . .] \text { já está assim positivamente regrado que a morte } \\
\text { encefálica é o preciso ponto terminal da personalizada existência humana. [...] } \\
\text { se, enfim, o embrião humano a que se reporta o art. } 5^{\circ} \text { da Lei de Biossegurança } \\
\text { constitui-se num ente absolutamente incapaz de qualquer resquício de vida } \\
\text { encefálica, então a afirmação de incompatibilidade deste último diploma } \\
\text { legal [o art. } 5^{\circ} \text { da Lei de Biossegurança] com a Constituição é de ser plena e } \\
\text { prontamente rechaçada".6 }\end{array}$ \\
\hline
\end{tabular}

\section{MINISTRA ELLEN GRACIE}

O voto da ministra acompanha a decisão do relator. Seu entendimento é, no entanto, diverso: o embrião não se classifica nem como pessoa (pois para isso precisaria ter nascido) e nem como nascituro (pois não há possibilidade que os embriões inviáveis venham a nascer), por isso não há como invocar a dignidade da pessoa humana. 


\begin{tabular}{|c|c|}
\hline Dados & $\begin{array}{l}\text { "Não se lhe pode opor, segundo entendo, a garantia da dignidade da pessoa } \\
\text { humana - artigo } 1^{\circ} \text {, inciso III -, nem a garantia de inviolabilidade da vida, } \\
\text { pois, conforme acredito, o pré-embrião não acolhido no seu ninho natural de } \\
\text { desenvolvimento - o útero - não se classifica como pessoa. A ordem jurídica } \\
\text { nacional atribui a qualificação de pessoa ao nascido com vida. Por outro lado, } \\
\text { o pré-embrião - ou ao menos aqueles de que aqui tratamos - ou seja, os } \\
\text { inviáveis e destinados ao descarte - também não se enquadra na condição de } \\
\text { nascituro, pois a esse - a própria denominação o esclarece bem - se pressupõe } \\
\text { a possibilidade, a probabilidade de vir a nascer, o que não acontece com esses } \\
\text { embriões inviáveis ou destinados ao descarte".7 }\end{array}$ \\
\hline Garantia & $\begin{array}{l}\text { "[...] somente após esse estágio, pré-embrionário, com duração de } 14 \text { dias, é } \\
\text { que surge o embrião como uma estrutura propriamente individual". }\end{array}$ \\
\hline Apoio & $\begin{array}{l}\text { Lição de Edward O. Wilson; Letícia Cesarino; o Human Fertilisation and } \\
\text { Embriology Act do Reino Unido. }\end{array}$ \\
\hline Conclusão & $\begin{array}{l}\text { "Assim, por verificar um significativo grau de razoabilidade e cautela no } \\
\text { tratamento normativo dado à matéria aqui exaustivamente debatida, não vejo } \\
\text { qualquer ofensa à dignidade humana na utilização de pré-embriões inviáveis } \\
\text { ou congelados há mais de três anos nas pesquisas de células-tronco, que não } \\
\text { teriam outro destino que não o descarte".9 }\end{array}$ \\
\hline
\end{tabular}

\section{MINISTRO MENEZES DIREITO}

Vota pela procedência em parte da ação, visando dar interpretações específicas aos termos da lei. Em linhas gerais, entende que as células-tronco embrionárias devem ser obtidas sem a destruição do embrião (além de vedar o descarte, delimitar a procedência dos embriões e o conceito de inviabilidade), que o consentimento dos genitores seja expresso e por escrito e que os projetos devem ser submetidos à aprovação do Ministério da Saúde. 


\section{Inviolabilidade do direito à vida}

\begin{tabular}{|c|c|}
\hline Dados & $\begin{array}{l}\text { "O embrião é, desde a fecundação, mais precisamente desde a união dos } \\
\text { núcleos do óvulo e do espermatozoide, um indivíduo, um representante da } \\
\text { espécie humana, com toda carga genética (DNA) que será a mesma do feto, } \\
\text { do recém-nascido, da criança, do adolescente, do adulto, do velho. Não há } \\
\text { diferença ontológica entre essas fases que justifique alguma proteção de sua } \\
\text { continuidade e a outras não". }{ }^{10}\end{array}$ \\
\hline Garantia & $\begin{array}{l}\text { Do ponto de vista filosófico, o ministro entende que "[...] o embrião não é ente } \\
\text { que se transmuda para além de sua essência. É o próprio ser em potência, e, } \\
\text { sobretudo, em essência, em ininterrupta atualização que em seus primeiros } \\
\text { estágios, e, mesmo em cultura, é representada por suas sucessivas divisões". }{ }^{11} \\
\text { Já com fundamentos biológicos, postula que "a embriologia moderna dispõe } \\
\text { de conhecimentos extraordinários e um dos mais importantes textos de } \\
\text { referência do mundo, o de Moore e Persault, ensina que o desenvolvimento } \\
\text { humano se inicia exatamente na fecundação". }{ }^{12}\end{array}$ \\
\hline Apoio & $\begin{array}{l}\text { Cita a doutrina Aristotélica e comentadores. Também cita a doutrina agostiniana, } \\
\text { e textos utilizados em faculdade de medicina. }\end{array}$ \\
\hline Conclusão & $\begin{array}{l}\text { "[...] os embriões submetidos a congelamento são embriões com vida e não é } \\
\text { o próprio congelamento que lhes retira tal condição. [...] Tampouco lhes retira } \\
\text { essa condição o fato de estarem congelados há mais de três anos. [...] O método } \\
\text { de extração de células-tronco embrionárias que acarrete a sua destruição } \\
\text { violará, na minha compreensão, o direito à vida de que cuida o caput do art. } \\
5^{\circ} \text { da Constituição da República. No ponto exato em que o autoriza, a lei é } \\
\text { inconstitucional". }{ }^{13}\end{array}$ \\
\hline
\end{tabular}




\section{MINISTRA CARMEN LÚCIA}

\begin{tabular}{|l|l|}
\hline Dados & $\begin{array}{l}\text { "Se as células-tronco embrionárias, nas condições previstas nas normas agora } \\
\text { analisadas, não vierem a ser implantadas no útero de uma mulher, serão elas } \\
\text { descartadas. Dito de forma direta e objetiva, e ainda que certamente mais } \\
\text { dura, o seu destino seria o lixo. Estaríamos não apenas criando lixo genético, } \\
\text { como, o que é igualmente gravíssimo, estaríamos negando àqueles embriões } \\
\text { a possibilidade de se lhes garantir, hoje, pela pesquisa, o aproveitamento para } \\
\text { a dignidade da vida".14 }\end{array}$ \\
\hline Garantia & $\begin{array}{l}\text { "Na espécie em apreço, a célula-tronco embrionária põe-se, na legislação } \\
\text { examinada, como uma dignidade, não havendo como se Ihe atribuir um } \\
\text { preço. Ao contrário. A busca tão apaixonada pela manutenção da liberdade } \\
\text { de pesquisa com ela é exatamente por ser cada uma delas insubstituível, e por } \\
\text { isso, na compreensão da dignidade que Ihe é dado conferir e realizar, põe-se } \\
\text { ao cuidado do cientista para realizar o único fim agora para ela vislumbrada } \\
{[. . .] " .5}\end{array}$ \\
\hline Apoio & $\begin{array}{l}\text { Para conceituar a dignidade, cita Kant, a Declaração dos Direitos sobre o } \\
\text { Genoma Humano e Direitos Humanos da UNESCO, A Carta das Nações Unidas } \\
\text { de 1945. Além disso, cita julgamento do STF e lições de Habermas e Dworkin. }\end{array}$ \\
\hline $\begin{array}{l}\text { àquele que mais precisa do seu resultado, não há razões constitucionais a } \\
\text { impor o entrave desse buscar para a dignificação da espécie humana. Creio } \\
\text { que a utilização da célula-tronco embrionária para a pesquisa e, conforme o } \\
\text { seu resultado, para o tratamento [...], não apenas não viola o direito à vida. } \\
\text { Antes, torna parte da existência humana o que vida não seria, dispondo para } \\
\text { os que esperam pelo tratamento a possibilidade real de uma nova realidade } \\
\text { de vida".16 }\end{array}$ \\
\hline
\end{tabular}




\section{MINISTRO RICARDO LEWANDOWSKI}

Vota pela procedência em parte da ação, tendo em vista o objetivo de dar uma interpretação específica aos dispositivos da lei. Seu entendimento é semelhante ao do Ministro Menezes Direito: a definição do conceito de inviável (ausência espontânea de clivagem), que os embriões não sejam destruídos ou comprometidos, que o consentimento dos genitores seja formalmente exteriorizado e informado e que os projetos de pesquisa devem ser submetidos também à prévia fiscalização de órgãos públicos.

\section{Sobre o conceito de inviabilidade}

\begin{tabular}{|c|c|}
\hline Dados & $\begin{array}{l}\text { "[...] o discrímem empregado pelo legislador para permitir a destruição de embriões a } \\
\text { partir de três anos de congelamento afigura-se infundado, sem sentido e destituído } \\
\text { de justificativa razoável, pois não há qualquer explicação lógica para conferir-se } \\
\text { tratamento diferenciado aos embriões tendo em conta apenas os distintos estágios } \\
\text { de criopreservação em que se encontram". }{ }^{17}\end{array}$ \\
\hline Garantia & $\begin{array}{l}\text { "O inciso II do art. } 5^{\circ} \text { [da Lei } 11.105 / 05 \text { ] também apresenta problemas do ponto de } \\
\text { vista de sua constitucionalidade, em especial quando examinado sob o prisma do } \\
\text { princípio da isonomia, estampado no art. } 5^{\circ} \text {, II, da Carta Magna, o qual se arrima no } \\
\text { postulado da dignidade da pessoa humana e tem como uma de suas vertentes o } \\
\text { axioma da não-discriminação". }{ }^{18}\end{array}$ \\
\hline Apoio & $\begin{array}{l}\text { Em relação ao aspecto ético, cita Horkheimer e Kant. Para conceituar a inviabilidade } \\
\text { do embrião, cita a legislação e a doutrina alemã, espanhola e francesa. Além disso, } \\
\text { cita a Declaração Universal sobre o Genoma Humano e doutrina constitucional, como } \\
\text { Celso Antônio Bandeira de Mello e Canotilho. }\end{array}$ \\
\hline Conclusão & $\begin{array}{l}\text { "O critério para a utilização de embriões criopreservados em pesquisas, pois, há } \\
\text { de compatibilizar-se com a definição de 'inviabilidade' acima proposta. Quer dizer, } \\
\text { enquanto tiverem potencial de vida, ou, por outro, enquanto for possível implantá-los } \\
\text { no útero da mãe, [...] a destruição de embriões congelados, a meu sentir, afigura-se } \\
\text { contrária aos valores da ordem constitucional". }{ }^{19}\end{array}$ \\
\hline
\end{tabular}




\section{MINISTRO EROS GRAU}

O Ministro Eros Grau é voto vencido, pois, embora vote pela improcedência da ação, propõe decisão aditiva. Em termos gerais, ele propõe que a pesquisa e a terapia devem ser autorizadas somente por comitê de ética e pesquisa do Ministério da Saúde, restringir a interpretação do sentido de "fertilização in vitro" e do conceito de embriões inviáveis.

\section{A necessidade de decisão aditiva}

\begin{tabular}{|c|c|}
\hline Dados & $\begin{array}{l}\text { "Cumpre a esta Corte enfatizar a circunstância de pesquisa e terapia a que refere } \\
\text { esse artigo } 5^{\circ} \text { não poderem, em coerência com a Constituição, ser praticadas de } \\
\text { modo irrestrito. A ela se impõe estabelecer alguns limites. [...] Essa construção } \\
\text { há de ser empreendida com enorme cautela, além do que esse artigo } 5^{\circ} \text { deixa } \\
\text { em aberto questões cuja solução, à margem dele, poderá resultar incompatível } \\
\text { com a ordem jurídica concreta instalada pela nossa Constituição. [...] O risco } \\
\text { da manipulação genética, o temor de que estejamos próximos à completa } \\
\text { reificação da vida posta à mercê dos desígnios e princípios sem princípios do } \\
\text { mercado }[\ldots . .]^{2}{ }^{20}\end{array}$ \\
\hline Garantia & $\begin{array}{l}\text { "O "mal", no caso e digo "mal" entre aspas esse "mal", a amplitude da permissão } \\
\text { veiculada pelo preceito legal, há de ser combatido mediante a prolação, por esta } \\
\text { Corte, de decisão aditiva visando a superar a incompletude [o vocábulo está } \\
\text { incorporado ao vernáculo] do artigo } 5^{\circ} \text { e parágrafos da Lei n. } 11.105 / 05^{21} .\end{array}$ \\
\hline Apoio & Cita Tomás de Aquino. \\
\hline Conclusão & $\begin{array}{l}\text { "O fato, no entanto, é que a amplitude da permissão veiculada pelos preceitos } \\
\text { que se examina no bojo da presente ADI, permissão concedida sob mínimas } \\
\text { reservas, incompatibiliza-a com o bloco de constitucionalidade delineado } \\
\text { pelo Supremo Tribunal Federal no quanto tem decidido, no conjunto de suas } \\
\text { deliberações, em termos de atribuição de força normativa à Constituição". }{ }^{22}\end{array}$ \\
\hline
\end{tabular}




\section{MINISTRO JOAQUIM BARBOSA}

Acompanhando o voto do relator e julgando a ação totalmente improcedente, o Ministro Joaquim Barbosa dá destaque no seu voto no princípio da livreexpressão científica e na autonomia da vontade dos genitores.

\begin{tabular}{|c|c|}
\hline Dados & $\begin{array}{l}\text { "[...] os genitores dos embriões produzidos por fertilização in vitro têm a sua } \\
\text { liberdade de escolha, ou seja, a sua autonomia privada e as suas convicções } \\
\text { morais e religiosas respeitadas pelo dispositivo ora impugnado. Ninguém } \\
\text { poderá obrigá-los a agir de forma contrária aos seus interesses, aos seus } \\
\text { sentimentos, às suas ideias, aos seus valores, à sua religião, e à sua própria } \\
\text { convicção acerca do momento em que a vida começa". }{ }^{23}\end{array}$ \\
\hline Garantia & $\begin{array}{l}\text { O Ministro entende que o direito à vida não é absoluto e deve-se ponderar } \\
\text { entre suas várias facetas. Nesse caso, o direito à vida deve ser entendido em um } \\
\text { sentido mais coletivo. Além disso, afirma que "[...] parece-me que a legislação } \\
\text { brasileira segue os critérios mínimos que têm sido exigidos por outros países } \\
\text { que permitem a pesquisa envolvendo células-tronco embrionárias". }{ }^{24}\end{array}$ \\
\hline Apoio & $\begin{array}{l}\text { Para a questão do direito à vida, cita seu entendimento no HC } 84.025 \text { e o debate } \\
\text { social causado pela lei. Além disso, cita a CF (art. } 5^{\circ} \text {, caput, VI e IX; art. 19, I) } \\
\text { e José Afonso da Silva. No direito comparado, cita a legislação da Inglaterra, } \\
\text { França, Espanha, Bélgica e Suíça. }\end{array}$ \\
\hline Conclusão & $\begin{array}{l}\text { "Assim, o melhor caminho para a proteção do direito à vida, em seus diversos } \\
\text { e diferentes graus, é uma legislação consciente e a existência de órgãos } \\
\text { dotados de competência técnica e normativa para implementá-la, fiscalizando } \\
\text { efetivamente a pesquisa cientifica no país. [...] Essa Corte, em de seu papel de } \\
\text { guardiã da Constituição Federal e dos direitos e garantias fundamentais, tem o } \\
\text { dever de proteger a democracia, a liberdade de crença religiosa e a liberdade } \\
\text { de investigação científica. A meu sentir, pedindo vênia aos que pensam de } \\
\text { maneira diferente, creio que a permissão para a pesquisa cientifica, tal como } \\
\text { disposta na lei ora atacada, não padece de inconstitucionalidade". }{ }^{25}\end{array}$ \\
\hline
\end{tabular}




\section{MINISTRO CEZAR PELUZO}

Embora julgue a ação improcedente, o Ministro Cezar Peluzo utiliza da interpretação conforme, para acentuar a autorização de uso de célulastronco embrionárias exclusivamente para pesquisas em fins terapêuticos, a responsabilidade penal dos membros dos comitês de ética e a Comissão Nacional de Pesquisa, além da necessidade de submissão das atividades de pesquisa a outros órgãos de controle e fiscalização estatais.

\begin{tabular}{|c|c|}
\hline Dados & $\begin{array}{l}\text { "[...] nem todo tratamento ou destinação última de células embrionárias se } \\
\text { harmonizam com o grau de valor ético e de tutela constitucional que se lhes } \\
\text { devem reconhecer, assumindo, em algumas hipóteses, com as de clonagem, } \\
\text { projetos eugênicos e engenharia genética, a natureza criminosa de severos } \\
\text { atentados à dignidade humana, mas nelas não se pode incluir o descarte de } \\
\text { embriões congelados. Por mais paradoxal que à primeira vista se revele, o } \\
\text { raciocínio não sofre, porque em si o embrião, que não pode vindicar sequer } \\
\text { expectativa de direito à vida, é deveras protegido pelo ordenamento jurídico, } \\
\text { mas tal proteção lhe não assegura direito subjetivo de evoluir e de nascer". }{ }^{26}\end{array}$ \\
\hline Garantia & $\begin{array}{l}\text { "Porque embriões congelados não têm vida atual, suscetível de proteção jurídica } \\
\text { plena (art. } 5^{\circ} \text {, caput), eliminá-los não constitui, em princípio, crime, nem ato ilícito } \\
\text { menos grave. Mas este juízo abstrato não dispensa o intérprete de apurar se, em } \\
\text { qualquer hipótese, independente do fim a que se predestine, está sempre salvo a } \\
\text { compatibilidade entre otipo de destruição de embriões excedentes ou inaproveitáveis } \\
\text { e a dignidade e o estatuto jurídico-constitucionais de que se revestem". }{ }^{27}\end{array}$ \\
\hline Apoio & $\begin{array}{l}\mathrm{CF} \text {, art. } 1^{\circ} \text { e } 5^{\circ} \text {, caput. Quanto ao começo da vida, faz longa digressão, baseado } \\
\text { principalmente em Koropkin e Roxin. }\end{array}$ \\
\hline Conclusão & $\begin{array}{l}\text { "E, nesse contexto, é mister extrair-lhe, ainda com apoio na técnica da } \\
\text { chamada interpretação conforme, todas as garantias inerentes à intangibilidade } \\
\text { constitucional do genoma humano, na sua expressão e valor de programa } \\
\text { hereditário que identifica, caracterizae distingue, nasuairredutível singularidade, } \\
\text { toda pessoa humana, sobretudo no plano prático das limitações necessárias } \\
\text { das pesquisas científicas e da regulamentação de um sistema de atribuição e } \\
\text { controle de responsabilidades, sem as quais não se passa dos apelos gerais à } \\
\text { instauração de uma práxis consentânea". } 28\end{array}$ \\
\hline
\end{tabular}




\section{MINISTRO MARCO AURÉLIO}

Julga pela improcedência da ação, destacando a inexistência de vida humana fora do útero materno e das possíveis consequências da vedação da Lei.

\begin{tabular}{|c|c|}
\hline Dados & $\begin{array}{l}\text { "Ora, o que previsto no artigo } 5^{\circ} \text { da Lei no } 11.105 / 2005 \text { objetiva, acima de tudo, } \\
\text { avançar no campo científico para preservar esse fundamento [a dignidade da } \\
\text { pessoa humana], para devolver às pessoas acometidas de enfermidade ou às } \\
\text { vítimas de acidente uma vida útil razoavelmente satisfatória. [...] Em outras } \\
\text { palavras, os valores cotejados não possuem a mesma envergadura, surgindo } \\
\text { triste paradoxo no que, ante material biológico que terá, repito, destino único } \\
\text { - o lixo - seja proibida a utilização para salvar vidas". }{ }^{29}\end{array}$ \\
\hline Garantia & $\begin{array}{l}\text { "[...] aqui não se trata de questionar a possibilidade de uma pessoa - a } \\
\text { gestante - a ficar fisicamente conectada a outra, [...] mas de definir o destino } \\
\text { dos óvulos fecundados, que fatalmente seriam destruídos e que podem - e } \\
\text { devem ser - aproveitados na tentativa, sempre inesgotável, de progresso da } \\
\text { humanidade".30 }\end{array}$ \\
\hline Apoio & $\begin{array}{l}\text { Cita, quanto à impossibilidade de haver vida no embrião, David Baltimore, lição } \\
\text { de José Afonso da Silva e entendimento de biólogos. Traz vários exemplos da } \\
\text { questão das células-tronco em outros países e a pesquisa que o Ibope realizou } \\
\text { sobre o assunto. }\end{array}$ \\
\hline Conclusão & $\begin{array}{l}\text { "Cumpre a esta Corte a guarda da Constituição Federal e a estará implementando } \\
\text { a todos os títulos, sob as mais diversas ópticas, vindo a julgar improcedente } \\
\text { o pleito formulado nesta ação direita de inconstitucionalidade, mantendo a } \\
\text { esperança, sem a qual a vida do homem torna-se inócua". }{ }^{31}\end{array}$ \\
\hline
\end{tabular}

MINISTRO CELSO DE MELLO

Também segue o voto do relator. No seu entendimento, a legislação infraconstitucional define um marco claro para a definição de vida: a presença de sistema nervoso. Além disso, acentua o caráter laico do estado. 


\begin{tabular}{|c|c|}
\hline Dados & $\begin{array}{l}\text { "[...] a questão pertinente ao direito à vida admite a possibilidade de, ele } \\
\text { próprio, constituir objeto de ponderação por parte do Estado, considerada a } \\
\text { relevantíssima circunstância [...] de que se põem em relação de conflito, com } \\
\text { esse mesmo direito, interesses existenciais graves e irreversíveis, cuja superação } \\
\text { pode ser conseguida com a liberação - que se impõe como uma exigência de } \\
\text { ordem ética e de caráter jurídico - das pesquisas científicas com células-tronco } \\
\text { embrionárias" }{ }^{\prime 32} \text { (p. 587). }\end{array}$ \\
\hline Garantia & $\begin{array}{l}\text { "A atividade cerebral, referência legal para a constatação da existência da } \\
\text { vida humana, pode, também, 'a contrario sensu', servir de marco definidor do } \\
\text { início da vida, revelando-se critério objetivo para afastar a alegação de que a } \\
\text { utilização de células-tronco embrionárias [...] transgrediria o postulado que } \\
\text { assegura a inviolabilidade do direito à vida. [...] É por isso, Senhor Presidente, } \\
\text { que não vislumbro paridade ontológica, no plano normativo, entre o embrião } \\
\text { [...] e a pessoa nascida". }{ }^{33}\end{array}$ \\
\hline Apoio & $\begin{array}{l}\text { Quanto ao início da vida, cita o documento elaborado pelo grupo de trabalho } \\
\text { da Academia Brasileira de Ciências, Letícia da Nóbrega Cesarino e pesquisa de } \\
\text { Eliza Muto e Leandro Narloch. Em matéria legal CF, art. 5; Lei n. 9434/97, art. } \\
3^{\circ} \text {. Além disso, cita o caso } 2141 \text { da Convenção Americana de Direitos Humanos } \\
\text { e várias declarações e pactos assinados pelo Brasil. }\end{array}$ \\
\hline Conclusão & $\begin{array}{l}\text { "Em uma palavra, Senhor Presidente, o luminoso voto proferido pelo eminente } \\
\text { Ministro Carlos Britto permitirá, a esses milhões de brasileiros que hoje sofrem } \\
\text { e que se acham postos à margem da vida, o exercício concreto de certos } \\
\text { direitos básicos e inalienáveis, dentre os quais avultam, por sua inquestionável } \\
\text { transcendência, o direito à busca da felicidade e o direito de viver com dignidade, } \\
\text { que constituem prerrogativas essenciais de que ninguém, absolutamente } \\
\text { ninguém, pode ser privado. Com essas considerações, peço vênia para julgar } \\
\text { improcedente, sem qualquer restrição, a presente ação direta e confirmar a } \\
\text { plena validade constitucional do art. } 5^{\circ} \text { da Lei de Biossegurança". }{ }^{34}\end{array}$ \\
\hline
\end{tabular}

\section{MINISTRO GILMAR MENDES}

O Ministro Gilmar Mendes é voto vencido, pois propõe decisão aditiva. Seu entendimento é de que falta na lei a previsão de instituição de um órgão central 
para analisar, aprovar e autorizar a pesquisa e a terapia com as células-tronco embrionárias.

\begin{tabular}{|c|c|}
\hline Dados & $\begin{array}{l}\text { "[...] é impossível negar a deficiência da lei brasileira na regulamentação } \\
\text { desse tema. [...] [Ela] sequer prevê qualquer norma para regular as atividades } \\
\text { desenvolvidas pelas clínicas de fertilização in vitro. [...] Deixa a lei, nesse } \\
\text { aspecto, de instituir um imprescindível Comitê Central de Ética, devidamente } \\
\text { regulamentado. [...] Além disso, é importante observar que a legislação no } \\
\text { direito comparado, sem exceção, estabelece, de forma expressa, uma cláusula } \\
\text { de subsidiariedade, no sentido de permitir as pesquisas com embriões humanos } \\
\text { apenas nas hipóteses em que outros meios científicos não se demonstrarem } \\
\text { adequados para os mesmos fins". }{ }^{35}\end{array}$ \\
\hline Garantia & $\begin{array}{l}\text { "Utilizando-sedaexpressãodeCanaris, pode-sedizerqueosdireitosfundamentais } \\
\text { expressam não apenas uma proibição do excesso (Übermassverbote), mas } \\
\text { também podem ser traduzidos como proibições de proteção insuficiente ou } \\
\text { imperativos de tutela (Untermassverbote). [...] O ato não será adequado quando } \\
\text { não proteja o direito fundamental de maneira ótima; não será necessário } \\
\text { na hipótese de existirem medidas alternativas que favoreçam ainda mais a } \\
\text { realização do direito fundamental; e violará o subprincípio da proporcionalidade } \\
\text { em sentido estrito se o grau de satisfação do fim legislativo é inferior ao grau } \\
\text { em que não se realiza o direito fundamental de proteção". }{ }^{36}\end{array}$ \\
\hline Apoio & $\begin{array}{l}\text { Quanto à doutrina alemã, cita Claus Wilhelm Canaris e outros doutrinadores, } \\
\text { além de diversas decisões do Tribunal Constitucional Alemão. No direito } \\
\text { comparado, cita detalhadamente a legislação e as decisões da Alemanha, da } \\
\text { Austrália, da França, da Espanha e do México. }\end{array}$ \\
\hline Conclusão & $\begin{array}{l}\text { "[...] deve-se conferir ao art. } 5^{\circ} \text { uma interpretação em conformidade com o } \\
\text { princípio responsabilidade, tendo como parâmetro de aferição o princípio da } \\
\text { proporcionalidade como proibição de proteção deficiente (Untermassverbot). } \\
\text { [...] O art. } 5^{\circ} \text { da Lei n. } 11.105 / 2005 \text { deve ser interpretado no sentido de que a } \\
\text { permissão da pesquisa e terapia com células-tronco embrionárias, obtidas de } \\
\text { embriões humanos produzidos por fertilização in vitro, deve ser condicionada à } \\
\text { prévia aprovação e autorização por Comitê (Órgão) Central de Ética e Pesquisa, } \\
\text { vinculado ao Ministério da Saúde". }{ }^{37}\end{array}$ \\
\hline
\end{tabular}




\section{A ARGUMENTAÇÃO JURÍDICA DA ADI N 3510: UMA ANÁLISE A PARTIR DAS CATEGORIAS DE NEIL MACCORMICK}

A análise realizada no tópico anterior permite observar como foram construídos os argumentos que compõem a decisão da ADI no 3510 - quais foram as conclusões dos ministros, quais foram os dados utilizados e quais as razões foram escolhidas como relevantes para embasar os argumentos. Passa-se agora a examinar a correção dos argumentos dessa decisão, tanto do ponto de vista interno quanto externo, à luz da teoria de Neil MacCormick.

Segundo essa teoria, quando existe uma situação de dúvida ou disputa em torno do sentido de alguma disposição legal - problemas, portanto, de interpretação -, deve-se decidir dando preferência a determinada leitura, considerada mais razoável no contexto. ${ }^{18} \mathrm{Na}$ ADI n ${ }^{0} 3510$, a ação gira em torno da interpretação disputada do art. $5^{\circ}$ da Lei n $11.105 / 05$, comojá foi dito. Ao dar preferência a uma das possíveis leituras, utilizam-se os argumentos que MacCormick chama de argumentos interpretativos, divididos em argumentos linguísticos, sistêmicos e teleológico-avaliativos.

De forma resumida, os argumentos linguísticos são os que apelam para o "sentido claro" de certas palavras ou de certos conceitos, o que pressupõe um contexto linguístico (ordinário ou técnico) que fornece uma melhor interpretação do sentido em disputa. ${ }^{19}$ Os argumentos sistêmicos são os que buscam compreender os dispositivos legais dentro do contexto - nesse sentido, "a parte faz sentido no contexto do todo, e a lei é um elemento do sistema jurídico como um todo". ${ }^{20}$ De forma geral, são argumentos que dão coerência e conteúdo ao Direito, na medida em que considera o sistema jurídico um sistema que deve ser interpretado de forma completa. Por fim, os argumentos teleológico-avaliativos são os que apontam para as finalidades ou objetivos de determinado dispositivo legal, interpretando de forma a obedecer a esses propósitos. A legislação, nesse sentido, também possuiria um sentido teleológico, voltado para determinadas finalidades. ${ }^{21}$

18 MACCORMICK, Neil. Retórica e o Estado de Direito, p. 161-165.

19 MACCORMICK, Neil. Retórica e o Estado de Direito, p. 167-169.

20 MACCORMICK, Neil. Retórica e o Estado de Direito, p. 169-170.

21 MACCORMICK, Neil. Retórica e o Estado de Direito, p. 175-182. 
A partir da análise segundo o layout de Toulmin, fica claro que nos votos da ADI n 3510 existem vários exemplos dessas espécies de argumento: argumentos que apelam para o sentido de "embrião" ou "vida"; argumentos que apelam para o contexto jurídico, invocando legislação infraconstitucional e acordos internacionais; argumentos que apelam para as consequências da ação, como o descarte de embriões. Esses argumentos buscam responder à dúvida central do julgamento - se as pesquisas com células-tronco embrionárias são constitucionais. Do ponto de vista individual, pode-se considerar que os votos são racionais, pois são justificados com argumentos jurídicos. Uma exceção que se poderia levantar, nesse quesito, seria o voto do Ministro Eros Grau, que, no nosso entendimento, não justifica de forma explícita a necessidade de decisão aditiva - seu raciocínio se constrói de forma a confirmar o entendimento de que a Lei é plenamente constitucional, porém vota em sentido distinto (basta conferir a análise realizada por meio do layout de Toulmin).

Para avaliar a argumentação jurídica, MacCormick também propõe que, tanto do ponto de vista dos votos quanto da decisão, sejam analisados os requisitos de consistência, coerência e universabilidade.

A consistência é um requisito formal. É a mera ausência de contradição lógica ou seja, a decisão não se contradiz nas suas fundamentações. ${ }^{22}$ Do ponto de vista individual, os votos não despertam muitas dúvidas em relação à consistência, sendo considerados, de um ponto de vista interno, racionais. Porém, tomada como um conjunto, a decisão apresenta problemas de consistência.

Antes de adentrar nesse quesito, é mister assinalar que, numa ordem democrática, é essencial que as pessoas possam divergir entre si, principalmente em questões polêmicas, como no presente caso. É esperado que essa divergência também se reflita no tribunal. No entanto, retomando a discussão inicial, é necessário que as decisões judiciais sejam adequadamente fundamentadas, o que se relaciona diretamente com valores como a segurança jurídica. Dessa forma, é possível que uma decisão inconsistente seja coerente (ponto que já se discutirá) com a ordem jurídica, já que frequentemente existem votos vencidos

22 MACCORMICK, Neil. Retórica e o Estado de Direito, p. 248. 
e opiniões divergentes em casos difíceis - basta que as razões da decisão sejam inteligíveis e que se possam identificar as razões dos votos vencedores e dos votos vencidos.

No presente caso, porém, a falta de consistência do julgamento não permite encontrar as razões que o tribunal apresenta para a decisão sem recorrer individualmente para os votos ou para uma contagem dos resultados. A ementa do julgamento, por exemplo, afirma que os ministros acordaram pela improcedência total da ação, vencendo por 6 votos a 5 . Se se questionar, no entanto, qual o entendimento vencedor, qual resposta se obteria?

A resposta mais fácil seria novamente apelar para a ementa, já que esta tem o intuito de resumir de forma concisa o conteúdo do acórdão. No presente caso, porém, parece que a ementa é uma colagem de vários votos, sem muita preocupação com as divergências e as inconsistências do julgamento. Dando um exemplo, a ementa postula a "inexistência de ofensas ao direito à vida e da dignidade da pessoa humana, pois a pesquisa com células-tronco embrionárias [...] significa a celebração solidária da vida e alento aos que se acham à margem do exercício concreto e inalienável dos direitos à felicidade e do viver com dignidade"23, explicitando que esse entendimento é do Ministro Celso de Mello (que votou pela improcedência da ação). Segundo a ementa, portanto, a dignidade da pessoa humana deve ser entendida em um sentido coletivo.

Compara-se esse entendimento com o do Ministro Ayres Britto (relator do caso), e a Ministra Ellen Gracie, os quais também votaram pela improcedência da ação. O Ministro Relator diz em seu voto: "apesar de nenhuma realidade ou forma de vida pré-natal ser uma pessoa física ou natural, ainda assim faz-se portadora de uma dignidade que importa reconhecer e proteger" 24 , entendendo que mesmo o embrião seria protegido pela dignidade da pessoa humana (mas não o embrião fora do útero, cf. p. 190-191). Já a ministra Ellen Gracie, embora pareça entender de modo semelhante, faz paralelo com o conceito de pessoa:

23 BRASIL. Supremo Tribunal Federal. Ação Direta de Inconstitucionalidade no 3510. Inteiro Teor do Acórdão. Relator: Ministro Ayres Britto. Julgado em 29 de maio de 2008. p. 136.

24 BRASIL. STF. Ação Direta de Inconstitucionalidade no 3510. Inteiro Teor do Acórdão, 2008, p. 171. 
"não se lhe pode opor, segundo entendo, a garantia da dignidade da pessoa humana [...] pois, conforme acredito, o pré-embrião não acolhido no seu ninho natural de desenvolvimento - o útero - não se classifica como pessoa". ${ }^{25}$

Nesse recorte, percebe-se que cada um dos três ministros - que votaram no mesmo sentido, pela improcedência da ação - possui uma concepção distinta do conceito de dignidade da pessoa humana. No caso, existem várias outras inconsistências desse gênero: sobre a definição do direito à vida, sobre a tutela do embrião e mesmo sobre o alcance da interpretação conforme (nos votos vencidos).

Se se examinar a interpretação do alcance do direito à vida, as divergências se acentuam. Uma das questões polêmicas foi a da necessidade de delimitar o início da vida humana para decidir o caso. Para o Ministro Ayres Britto ${ }^{26}$ e para a Ministra Carmen Lucia ${ }^{27}$, não é necessário dizer qual é o início da vida para decidir no caso. Porém, para o Ministro Ayres Britto, "a questão não reside exatamente em se determinar o início da vida do homo sapiens, mas em saber que aspectos ou momentos dessa vida estão validamente protegidos pelo Direito infraconstitucional e em que medida"28; já para a Ministra Carmen Lúcia, "[se] há de afirmarem os princípios constitucionais e a sua aplicação ao caso". ${ }^{29}$

O Ministro Celso de Mello entende que, por conta das divergências religiosas e científicas acerca do início da vida, é permitido "ao intérprete necessariamente desvinculado de razões de natureza confessional ou religiosa -, optar por aquela concepção que mais se ajuste ao interesse público"30; o Ministro Joaquim Barbosa concorda com a posição de que o caso não trata da

25 BRASIL. STF. Ação Direta de Inconstitucionalidade no 3510. Inteiro Teor do Acórdão, 2008, p. 212.

26 BRASIL. STF. Ação Direta de Inconstitucionalidade no 3510. Inteiro Teor do Acórdão, 2008, p. 165-166.

27 BRASIL. STF. Ação Direta de Inconstitucionalidade no 3510. Inteiro Teor do Acórdão, 2008, p. 331.

28 BRASIL. STF. Ação Direta de Inconstitucionalidade no 3510. Inteiro Teor do Acórdão, 2008, p. 165-166.

29 BRASIL. STF. Ação Direta de Inconstitucionalidade no 3510. Inteiro Teor do Acórdão, 2008 , p. 331.

30 BRASIL. STF. Ação Direta de Inconstitucionalidade no 3510. Inteiro Teor do Acórdão, 2008, p. 579. 
definição do início da vida ${ }^{31}$ e entende que é possível ponderar entre as várias facetas do direito à vida, e que o Congresso Nacional "optou por aquela que alia a proteção da vida num sentido mais amplo e coletivo com o desenvolvimento científico dentro de determinadas balizas". 32

Os quatros votos acima foram no mesmo sentido: a improcedência da ação. Eles deixam transparecer que, diante dos principais fundamentos jurídicos do acórdão (a interpretação do direito à vida e o direito à dignidade da pessoa humana, fundamentos da petição inicial), existiu divergência entre os ministros.

À luz da teoria de Neil MacCormick, outro aspecto igualmente relevante para a análise é o requisito da coerência, mais especificamente a coerência normativa. A coerência normativa é uma relação entre as normas aplicáveis ao caso e aos valores que tenham um objetivo maior; valores que, nesse conjunto, "expressem uma forma de vida satisfatória" ${ }^{\prime 3}$. Se um conjunto de normas é aplicado em relação a um objetivo maior - um valor comum, como dignidade ou justiça pode-se dizer que essas normas são aplicadas de forma coerente.

Para o autor, os valores de um Estado Democrático de Direito, como a segurança e a certeza jurídica, só podem ser concretizados na medida em que existam regras pré-anunciadas que sejam claras e inteligíveis, contidas em um sistema jurídico consistente e que mantenha uma coerência geral dos princípios inclusos no sistema. ${ }^{34}$ Uma decisão deve decorrer do direito preexistente e estar em consonância com os princípios e os valores do sistema jurídico aceitos pela comunidade, e essa exigência está ligada aos ideais de igualdade de tratamento e à universalização das decisões. ${ }^{35}$ Por esse motivo, a coerência é um dos critérios para avaliar certa decisão como justa ou boa. ${ }^{36}$

31 BRASIL. STF. Ação Direta de Inconstitucionalidade no 3510. Inteiro Teor do Acórdão, 2008, p. 462.

32 BRASIL. STF. Ação Direta de Inconstitucionalidade no 3510. Inteiro Teor do Acórdão, 2008, p. 463.

33 MACCORMICK, Neil. Retórica e o Estado de Direito, p. 252.

34 MACCORMICK, Neil. Retórica e o Estado de Direito, p. 17.

35 MARTINS, Argemiro Cardoso Moreira; ROESLER, Claudia Rosane; JESUS, Ricardo Antonio Rezende de. A noção de coerência na teoria da argumentação jurídica de Neil MacCormick: caracterização, limitações, possibilidades. Revista Novos Estudos Jurídicos, v. 16, n. 2, mai./ago. 2011, p. 218. Disponível em: http://siaiweb06.univali.br/seer/index.php/nej/ article/view/ 3281.

36 MARTINS, Argemiro Cardoso Moreira; ROESLER, Claudia Rosane; JESUS, Ricardo Antonio Rezende de. A noção de coerência na teoria da argumentação jurídica de Neil MacCormick: 
A partir do crivo da coerência, deve-se questionar se a decisão da ADI n 3510 está em harmonia com os princípios e com os valores que dão sentido, nesse conjunto, ao nosso ordenamento jurídico.

No decurso da análise, percebeu-se que o caso é extremamente singular, de forma que se precisa desdobrar a análise da coerência em dois planos: um plano interno (que diz respeito aos fundamentos do caso) e um plano externo (que diz respeito à decisão em si). À primeira vista, chegou-se a uma conclusão paradoxal: embora internamente, não se pode dizer que uma decisão com esse grau de inconsistência é coerente com os valores que norteiam o ordenamento jurídico (principalmente a segurança jurídica), do ponto de vista externo não se consegue dentro do contexto e ordenamento jurídico brasileiro - vislumbrar outra decisão.

Em outras palavras, parece evidente que a permissão das pesquisas com células-tronco embrionárias, nos termos e limitações da Lei n 11.105/05, era a melhor resposta que o tribunal poderia dar naquele momento; por outro lado, a fragmentação e a discordância interna da decisão, que não permite vislumbrar com clareza as razões que motivaram o julgamento, não são compatíveis com os valores e com os princípios que orientam e dão sentido ao ordenamento jurídico brasileiro. Dessa forma, considera-se que a decisão, embora coerente do ponto de vista externo, é incoerente do ponto de vista interno.

Por fim, precisa-se questionar se a decisão cumpre com o requisito de universabilidade. A universabilidade é a garantia de que situações concretas iguais terão respostas iguais do ponto de vistajurídico. Os elementos particulares do caso sempre serão levados em consideração, mas mesmo no caso mais particular e específico deve se cumprir com esse critério - de forma que, se esse caso se repetir nas mesmas circunstâncias e particularidades, deve ser dado tratamento jurídico igual. ${ }^{37}$

Se as decisões jurídicas devem ser universabilizáveis, ou seja, se os argumentos construídos para justificar uma decisão concreta devem poder ser reproduzidos

caracterização, limitações, possibilidades. Revista Novos Estudos Jurídicos, v. 16, n. 2, maio/ago. 2011, p. 216.

37 MACCORMICK, Neil. Retórica e o Estado de Direito, p. 103-133. 
em qualquer outro caso igual nas suas particularidades, não se consegue vislumbrar que a decisão tomada na ADI n ${ }^{\circ} 3510$ cumpre com esse requisito. Como universabilizar uma decisão jurídica que apresenta tal grau de incoerência?

\section{CONSIDERAÇÕES FINAIS}

Retomando o questionamento do início do artigo, se as leis e decisões possuírem apenas um "simulacro de inteligibilidade", elas não podem ser compatíveis com os valores e com os objetivos buscados por um Estado Democrático de Direito. Questionando, ao fim e ao cabo, qual é o entendimento da corte, fica-se diante de um paradoxo: não se consegue responder à questão sem recorrer às diversas razões que são encontradas nos votos individuais e que nem sempre guardam compatibilidade entre si.

Por mais que, do ponto de vista dos seus resultados, a autorização das pesquisas com células-tronco embrionárias tenha sido a melhor opção que a Suprema Corte poderia ter feito naquele momento, acredita-se que a justificação da decisão não foi igualmente satisfatória. Não por conta da utilização no julgamento de argumentos não racionais ou não pertinentes - todos os bons argumentos em torno do assunto foram levantados ao longo do julgamento -, mas porque argumentos em sentidos distintos e que levam a conclusões distintas sobre os fundamentos jurídicos do caso foram utilizados por ministros e ministras que votaram no mesmo sentido.

A decisão tomada por um órgão colegiado se chama acórdão, já que os magistrados acordam sobre certo tema. Resolvem de comum acordo, portanto, deixando espaço aos votos dissidentes. No presente caso, a maioria acordou em autorizar a pesquisa com células-tronco embrionárias, mas tal concordância não se reflete nos fundamentos dos votos. Acredita-se que isso não é compatível aos ideais de um Estado Democrático de Direito, pois vai de encontro com o ideal de segurança jurídica, fundamental em uma democracia.

Infelizmente a situação retratada nesta análise específica, que versou sobre a ADI 3510 e procurou explorar a argumentação judicial nela realizada, não é um fato 
isolado e sem repetição na prática da corte constitucional brasileira. Como outros estudos realizados no âmbito do mesmo projeto de pesquisa demonstraram ${ }^{38}$, tal ausência de uma fundamentação clara e compreensível aparece em decisões igualmente importantes para a definição dos direitos fundamentais, como a que reconheceu a possibilidade de união homoafetiva.

O que se pode depreender das análises realizadas ao longo da pesquisa já mencionada no início deste artigo, é que o STF argumenta de modo extenso ou mesmo prolixo, mas sem oferecer um arrazoado que seja compatível com o dever de fundamentação mencionado acima. Razões institucionais certamente concorrem para isto, assim como uma cultura argumentativa que ressalta as dimensões autoritativas das decisões tomadas pelos ministros.

Dentre as razões institucionais, pode-se listar a forma pela qual os julgamentos são organizados, com votos individuais dos ministros sendo lidos em plenário, normalmente preparados de antemão, sobretudo nos casos relevantes e de grande repercussão, e sem uma discussão real dos fundamentos de cada opinião ou um contraste dos argumentos e das teses que fundamentam a decisão oferecida pelo relator pela maioria ou pelos dissidentes.

Assim como se viu ao longo deste artigo, não é incomum que questões relevantes sejam levantadas em um dos votos e fiquem sem resposta, ocasionando ao intérprete dar sentido ao conjunto da decisão, a perplexidade de explicar o ponto médio entre as diversas posições ou opiniões.

38 Veja-se, por exemplo, as seguintes análises: ROESLER, Claudia R.; SENRA, Laura Carneiro de Mello. Lei de Anistia e Justiça de Transição: a releitura da ADPF 153 sob o viés argumentativoprincipiológico. Sequência, volume 64, p. 131-160, 2012. Disponível em: periodicos.ufsc. br/ index.php/sequencia/article/view/2177-7055.2012v33n64p131. ROESLER, Claudia R.; LAGE, Leonardo. A argumentação do Supremo Tribunal Federal e do Superior Tribunal de Justiça acerca da periculosidade de agentes inimputáveis e semi-imputáveis. Revista Brasileira de Ciências Criminais, ano 21, n. 104, set./out., 2013, p. 347-389. MOREIRA, Larissa Learth. Análise do Julgamento do caso Ficha Limpa sob o viés Argumentativo e Principiológico. Relatório de Pesquisa de Iniciação Científica 2011-2012. Programa de Iniciação Científica CNPq/UnB. ROESLER, Claudia R.; SENRA, Laura Carneiro de Mello. Gênero e Justiça de Transição no Brasil. Revista Jurídica da Presidência, vol. 15, n. 105, fev./mai 2013, p. 35-67. Disponível em: www4.planalto.gov.br/revistajuridica/vol-15-n105-edicao-especial-fev-mai-2013/menu-vertical/ apresentacao/rjp-105.pdf. CHAIM, Caio C. A Relação entre Legislativo e Judiciário na dinâmica democrática: Análise do caso da Lei Seca sob o viés argumentativo-principiológico. Relatório de Pesquisa de Iniciação Científica 2012-2013. Programa de Iniciação Científica CNPq/UnB. ROESLER, Claudia R.; SANTOS, Paulo Alves. Argumentação jurídica utilizada pelos tribunais brasileiros ao tratar das uniões homoafetivas. Artigo aceito para publicação em Revista Direito GV. 
No que tange à cultura argumentativa dos tribunais brasileiros, é possível encontrar indícios bastante claros de que ela é consistentemente orientada por uma perspectiva mais preocupada com a afirmação da individualidade ou do brilho pessoal de cada um dos decisores do que com uma decisão propriamente colegiada.

Em qualquer um desses ângulos de abordagem, parece relevante mostrar como uma decisão da importância da tomada na ADI 3510 poderia ser mais bem cuidada do ponto de vista argumentativo, ainda que o teor da decisão pudesse ser o mesmo. Este cuidado expressaria, sem dúvida, um maior respeito aos ideais de um Estado Democrático de Direito e expressaria de modo mais adequado o valor da coerência normativa.

\section{REFERÊNCIAS}

ATIENZA, Manuel. Las razones del derecho: teorías de la argumentación jurídica. 2. ed. México: Universidad Nacional Autónoma de México, 2005.

BRASIL. Congresso Nacional. PL 2401/2003. Inteiro Teor da Apresentação do Projeto de Lei pelo Poder Executivo. Outubro de 2003.

. Supremo Tribunal Federal. Ação Direta de Inconstitucionalidade $\mathbf{n}^{\circ}$ 3510. Inteiro Teor do Acórdão. Relator: Ministro Ayres Britto. Julgado em 29 de maio de 2008.

. Lei $\mathbf{n}^{\mathbf{0}} \mathbf{1 1 . 1 0 5}$, de 25 de março de 2005. Disponível em: http://www.planalto.gov.br/ ccivil_03/_ato2004-2006/2005/lei//11105.htm. Acessado em 5 ago. 2014.

CHAIM, Caio C. A Relação entre Legislativo e Judiciário na dinâmica democrática: Análise do caso da Lei Seca sob o viés argumentativo-principiológico. Relatório de Pesquisa de Iniciação Científica 2012-2013. Programa de Iniciação Científica CNPq/UnB.

MACCORMICK, Neil. Retórica e o Estado de Direito. Trad. Conrado Hübner Mendes e Marcos Paulo Veríssimo. Rio de Janeiro: Elsevier, 2008.

MARINONI, Luiz Guilherme. Teoria Geral do Processo. 3. ed. São Paulo: Editora Revista dos Tribunais, 2008.

MARTINS, Argemiro Cardoso Moreira; ROESLER, Claudia Rosane; JESUS, Ricardo Antonio Rezende de. A noção de coerência na teoria da argumentação jurídica de Neil MacCormick: caracterização, limitações, possibilidades. Revista Novos Estudos Jurídicos, v. 16, n. 2, mai./ ago. 2011. Disponível em: http://siaiweb06.univali.br/seer/index.php/nej/article/view/3281. 
MOREIRA, Larissa Learth. Análise do Julgamento do caso Ficha Limpa sob o viés Argumentativo e Principiológico. Relatório de Pesquisa de Iniciação Científica 2011-2012. Programa de Iniciação Científica - CNPq/UnB.

ROESLER, Claudia R.; LAGE, Leonardo. A argumentação do Supremo Tribunal Federal e do Superior Tribunal de Justiça acerca da periculosidade de agentes inimputáveis e semiimputáveis. Revista Brasileira de Ciências Criminais, ano 21, n. 104, set./out., 2013, p. 347389.

ROESLER, Claudia R.; SANTOS, Paulo Alves. Argumentação jurídica utilizada pelos tribunais brasileiros ao tratar das uniões homoafetivas. Artigo aceito para publicação em Revista Direito GV.

ROESLER, Claudia R.; SENRA, Laura Carneiro de Mello. Lei de Anistia e Justiça de Transição: a releitura da ADPF 153 sob o viés argumentativo-principiológico. Sequência, volume 64, p. 131-160, 2012. Disponível em: periodicos.ufsc.br/index.php/sequencia/article/view/21777055.2012 v33n64p131.

ROESLER, Claudia R.; SENRA, Laura Carneiro de Mello. Gênero e Justiça de Transição no Brasil. Revista Jurídica da Presidência, vol. 15, n. 105, fev./mai 2013, p. 35-67. Disponível em: www4. planalto.gov.br/revistajuridica/vol-15-n-105-edicao-especial-fev-mai-2013/menu-vertical/ apresentacao/rjp-105.pdf.

TOULMIN, Stephen E. Os usos do argumento. Trad. Reinaldo Guarany. 2. ed. São Paulo: Martins Fontes, 2006.

WALDRON, Jeremy. The concept and the Rule of Law. In: HeinOnline 43 Ga. L. Rev. 1 (20082009).

\section{NOTAS}

1 BRASIL. STF. Ação Direta de Inconstitucionalidade no 3510. Inteiro Teor do Acórdão, 2008, p. 163-164.

2 BRASIL. STF. Ação Direta de Inconstitucionalidade no 3510. Inteiro Teor do Acórdão, 2008, p. 161-162

3 BRASIL. STF. Ação Direta de Inconstitucionalidade no 3510. Inteiro Teor do Acórdão, 2008, p. 165-166.

4 BRASIL. STF. Ação Direta de Inconstitucionalidade no 3510. Inteiro Teor do Acórdão, 
2008, p. 198.

5 BRASIL. STF. Ação Direta de Inconstitucionalidade no 3510. Inteiro Teor do Acórdão, 2008, p. 196-197.

6 BRASIL. STF. Ação Direta de Inconstitucionalidade no 3510. Inteiro Teor do Acórdão, 2008, p. 201-202.

7 BRASIL. STF. Ação Direta de Inconstitucionalidade no 3510. Inteiro Teor do Acórdão, 2008, p. 212-213.

8 BRASIL. STF. Ação Direta de Inconstitucionalidade no 3510. Inteiro Teor do Acórdão, 2008, p. 216.

9 BRASIL. STF. Ação Direta de Inconstitucionalidade no 3510. Inteiro Teor do Acórdão, 2008, p. 219.

10 BRASIL. STF. Ação Direta de Inconstitucionalidade no 3510. Inteiro Teor do Acórdão, 2008, p. 277.

11 BRASIL. STF. Ação Direta de Inconstitucionalidade no 3510. Inteiro Teor do Acórdão, 2008, p. 271.

12 BRASIL. STF. Ação Direta de Inconstitucionalidade no 3510. Inteiro Teor do Acórdão, 2008, p. 276.

13 BRASIL. STF. Ação Direta de Inconstitucionalidade no 3510. Inteiro Teor do Acórdão, 2008, p. 284.

14 BRASIL. STF. Ação Direta de Inconstitucionalidade no 3510. Inteiro Teor do Acórdão, 2008 , p. 351.

15 BRASIL. STF. Ação Direta de Inconstitucionalidade no 3510. Inteiro Teor do Acórdão, 2008, p. 353.

16 BRASIL. STF. Ação Direta de Inconstitucionalidade no 3510. Inteiro Teor do Acórdão, 2008, p. 367.

17 BRASIL. STF. Ação Direta de Inconstitucionalidade no 3510. Inteiro Teor do Acórdão, 2008, p. 437.

18 BRASIL. STF. Ação Direta de Inconstitucionalidade no 3510. Inteiro Teor do Acórdão, 2008, p. 435-436.

19 BRASIL. STF. Ação Direta de Inconstitucionalidade no 3510. Inteiro Teor do Acórdão, 2008 , p. 439.

20 BRASIL. STF. Ação Direta de Inconstitucionalidade no 3510. Inteiro Teor do Acórdão, 2008, p. 457-458.

21 BRASIL. STF. Ação Direta de Inconstitucionalidade no 3510. Inteiro Teor do Acórdão, 2008, p. 459.

22 BRASIL. STF. Ação Direta de Inconstitucionalidade no 3510. Inteiro Teor do Acórdão, 2008, p. 457.

23 BRASIL. STF. Ação Direta de Inconstitucionalidade no 3510. Inteiro Teor do Acórdão, 2008, p. 467. 
24 BRASIL. STF. Ação Direta de Inconstitucionalidade no 3510. Inteiro Teor do Acórdão, 2008 , p. 472.

25 BRASIL. STF. Ação Direta de Inconstitucionalidade no 3510. Inteiro Teor do Acórdão, 2008, p. 474.

26 BRASIL. STF. Ação Direta de Inconstitucionalidade no 3510. Inteiro Teor do Acórdão, 2008, p. 516-517.

27 BRASIL. STF. Ação Direta de Inconstitucionalidade no 3510. Inteiro Teor do Acórdão, 2008, p. 515.

28 BRASIL. STF. Ação Direta de Inconstitucionalidade no 3510. Inteiro Teor do Acórdão, 2008, p. 519.

29 BRASIL. STF. Ação Direta de Inconstitucionalidade no 3510. Inteiro Teor do Acórdão, 2008, p. 548.

30 BRASIL. STF. Ação Direta de Inconstitucionalidade no 3510. Inteiro Teor do Acórdão, 2008, p. 547.

31 BRASIL. STF. Ação Direta de Inconstitucionalidade no 3510. Inteiro Teor do Acórdão, 2008, p. 552.

32 BRASIL. STF. Ação Direta de Inconstitucionalidade no 3510. Inteiro Teor do Acórdão, 2008, p. 587.

33 BRASIL. STF. Ação Direta de Inconstitucionalidade no 3510. Inteiro Teor do Acórdão, 2008, p. 582.

34 BRASIL. STF. Ação Direta de Inconstitucionalidade no 3510. Inteiro Teor do Acórdão, 2008, p. 591.

35 BRASIL. STF. Ação Direta de Inconstitucionalidade no 3510. Inteiro Teor do Acórdão, 2008, p. 620-622.

36 BRASIL. STF. Ação Direta de Inconstitucionalidade no 3510. Inteiro Teor do Acórdão, 2008, p. 608-610.

37 BRASIL. STF. Ação Direta de Inconstitucionalidade no 3510. Inteiro Teor do Acórdão, 2008, p. 630. 